\title{
Motif Keterlibatan Kaum Ibu dalam Pendidikan Anak Usia Dini di Jakarta Barat
}

\author{
Fitriani F.Syahrul $^{1 *}$, Fidesrinur ${ }^{2}$, Masni Erika Firmiana ${ }^{3}$ \\ ${ }^{1,2,3)}$ Fakultas Psikologi dan Pendidikan, Universitas AlAzhar Indonesia, Jl. Sisingamangaraja, Jakarta 12110. \\ Telp. 021-7244456, Fax. 021-7244767, "email: fitirani@uai.ac.id
}

Abstract- In solving Early Childhood Education (ECE) problems comprehensively and tactfully need to involve parents and community, especially mothers. Involving mothers in ECE aim at empowering them to educate their children, so they are not only depending on government program.

Spectacular growth of ECE institution is about 13 institution at Grogol sub-district in the two years shows that the role of mothers' association called PKK in ECE. The mothers' association participation on ECE is interesting and fascinating to investigate where at the same time the government tries to increase mothers emancipation. On the other hand the euphoria of ECE growth needs well manage for continuity. The continuity of ECE program are questioned because most of teachers and managers are not well educated on ECE. Most of them are Junior High School graduates, pension or an house wife. The research are trying to investigate, (1) what is the motive of the mothers involvement in ECE institution? (2) what is mothers idea about ECE continuity in dealing with budgeting, services, and quality of education.

Based on data collected from 80 respondent using questioner and analyzed by descriptive statistic and qualitative. The research findings are as follows: Firstly, the involvement of mothers are to act devotion by helping other people, to implement their knowledge and their experience in former job, and the need for achievement; secondly, the mothers idea about the ECE continuity are finding for donation, socialization the important of ECE, and increasing teacher competence through training.

Keywords - motive, motivation, ECE, prosocial behaviour, need for achievement

\section{PENDAHULUAN}

Kebijakan pemerintah menetapkan prioritas L pendidikan dasar pada Pendidikan Dasar 9 Tahun menjadikan pendidikan anak usia dini (usia 0-6 tahun) kurang mendapat prioritas. Pada tahun 2006 tercatat partisipasi masyarakat di bidang PAUD baru 28, 3 juta (46 \%) dari 13.223.812 jiwa anak (Direktorat PAUD, 2007:18). Padahal hasil penelitian Pendidikan Anak Usia Dini (PAUD) dari berbagai sudut pandang penelitian telah menyimpulkan bahwa anak usia dini adalah masa emas/ golden age dimana periode perkembangan kognitif, bahasa dan sosial emosional mengalami titik puncaknya. Keterlambatan stimulasi pada usia ini mempunyai efek jangka panjang dalam kehidupan seorang manusia.

Hasil penelitian lainnya membuktikan bahwa terdapat perbedaan antara anak yang terdidik dengan baik di usia dini dengan yang tidak terdidik di usia dini. Pemberian pendidikan yang berkualitas pada anak usia dini berpengaruh terhadap peningkatan perkembangan otak, peningkatan kesehatan, kesiapan anak bersekolah, serta kehidupan sosial dan ekonomi yang lebih baik di usia dewasanya.

Kenyataan ini menunjukkan bahwa masalah pendidikan tidak mungkin terselesaikan pemerintah tanpa melibatkan orang tua dan masyarakat. Kenyataan menunjukkan bahwa kebiasaan masyarakat menunggu program pendidikan yang digulirkan pemerintah, disamping membutuhkan biaya yang besar juga terkendala oleh keterbatasan pemerintah dalam sarana dan prasarana pendidikan.

Pesatnya pertumbuhan Lembaga Pendidikan Anak Usia Dini di Jakarta dalam dua tahun terakhir tidak terlepas dari upaya keras kaum wanita. Kecamatan Grogol Petamburan Jakarta Barat misalnya telah berdiri 13 Lembaga PAUD baru. Lembaga ini didirikan dan dikelola kaum kaum ibu seperti ibu-ibu PKK dan ibu-ibu rumah tangga yang diawali dengan kegiatan Pos Yandu. 
Partisipasi kaum ibu ini sangat menarik dan membanggakan disaat pemerintah berupaya meningkatkan emansipasi kaum ibu dalam pembangunan masyarakat berbangsa dan bernegara.

Pertambahan jumlah PAUD dalam jumlah besar ini perlu pemikiran untuk keberlanjutannya, apalagi jika pendirian sekolah PAUD hanya sekadar euforia masyarakat yang bersifat sesaat. Kekhawatiran ini makin nyata dengan keterbatasan kaum kaum ibu pengurus lembaga PAUD yang sebagian besar ibu rumah tangga, sehingga muncul pertanyaan apakah mereka mampu mengelola lembaga PAUD secara berkelanjutan. Untuk mengetahui semua itu perlu diketahui motif keterlibatan kaum ibu dalam lembaga PAUD serta proyeksi mereka terhadap keberlanjutan PAUD baik dari segi pendanaan, pelayanan, dan kualitas pendidikan.

Berdasarkan latar belakang yang dikemukakan di atas maka pertanyaan penelitian ini dapat dirumuskan sebagai berikut:

1. Faktor-faktor apa sajakah yang melatarbelakangi motivasi kaum ibu sebagai pengurus dan pendidik Lembaga Pendidikan Anak Usia Dini?

2. Apakah strategi yang dikembangkan kaum ibu pengurus dan pendidik PAUD dalam mengupayakan keberlanjutan Lembaga Pendidikan Anak Usia Dini?

Penelitian ini diharapkan dapat memberikan manfaat kepada pengambil keputusan dan pemerintah Daerah Jakarta Barat khususnya dalam mendorong partisipasi perempuan dalam pengelolaan dan keberlanjutan Lembaga PAUD dalam peransertanya mendidik kanak-kanak kalangan masyarakat miskin.

Bagi pengembangan ilmu, kajian ini dapat bermanfaat sebagai acuan dasar bagi pengelolaan partisipasi ibu-ibu dalam PAUD. Selain itu, hasil penelitian ini dapat memberikan nuansa baru dalam Psikologi dan Sosiologi Pendidikan khususnya motif keterlibatan perempuan dalam pengelolaan dan pelaksanaan pendidikan di Lembaga PAUD di Indonesia, khususnya di wilayah perkotaan.

\section{DESKRIPSI TEORETIS}

\section{Pentingnya Keterlibatan Kaum Ibu dalam Pendidikan Anak Usia Dini}

Pentingnya Pendidikan Anak Usia Dini telah banyak diteliti para ahli. Satu di antaranya Lindsey dalam Arce (2000:07) bahwa perkembangan jaringan otak dan periode perkembangan kritis secara signifikan terjadi pada tahun-tahun usia dini, dan perkembangan tersebut sangat ditentukan oleh lingkungan dan pengasuhan. Lingkungan dalam pengertian ini menurut Shore dalam Arce (2000:08) sebelum anak lahir, saat pembentukan sirkuit otak anak terjadi. Selanjutnya Feldman (2002) mengemukakan bahwa masa balita merupakan masa emas yang tidak akan berulang karena merupakan masa paling penting dalam pembentukan dasar-dasar kepribadian, kemampuan berfikir, kecerdasan, keterampilan, dan kemampuan bersosialisasi. Kenyataan ini memperkuat keyakinan kita bahwa pendidikan dasar bagi anak seyogianya dimulai sedini mungkin, tidak hanya dimulai di usia Sekolah Dasar, kemungkinan pengembangan potensi anak mulai berkurang. Tambahan lagi penelitian tentang otak menunjukkan sampai usia 4 tahun tingkat kapabilitas kecerdasan anak telah mencapai 50\%, pada usia 8 tahun mencapai $80 \%$, dan sisanya hanya sekitar $20 \%$ diperoleh pada saat berusia 8 tahun ke atas.

Selanjutnya Froebel dalam Brewer (2007:41) mengatakan bahwa permainan dalam pendidikan anak usia dini merupakan fondasi bagi pembelajaran anak sehingga dapat menjembatani anak antara kehidupan di rumah dan kehidupan anak di sekolah. Hal ini perlu menjadi perhatian karena pengaruh ibu terhadap perkembangan sosial anak tidak berhenti bersamaan dengan masuknya anak ke sekolah. Bahkan keterlibatan orang tua dalam seminar-seminar yang berkaitan dengan upaya peningkatan keterampilan berinteraksi dengan anak menunjukkan hasil yang sangat baik terhadap perkembangan sosial anak-anak mereka (Yussen \& Santrock, 1980:373).

Hasil penelitian yang dilakukan oleh Allison Clarke-Stewart dalam Yussen \& Santrock (1980:372-373) terhadap ibu dan anak menunjukkan bahwa perilaku ibu dan anak terbentuk dalam satu faktor yang kompleks dari "ibu yang baik" yang disebut pengasuhan ibu yang optimal optimal maternal care. Menjadi ibu yang baik menurut Arce (2000:07) membutuhkan pemahaman yang baik terhadap perkembangan anak. Artinya memahami bagaimana anak berubah sepanjang hidupnya baik perubahan fisik, perilaku, dan karakteristik berpikir, karena itu mengajar anak dengan baik berarti harus mempelajari anak itu sendiri.

Mengingat pendidikan anak merupakan bagian integral dari pendidikan sekolah, orang tua dan masyarakat, maka peserta didik usia dini 0-6 tahun yang tidak terlayani di Pos PAUD, Taman 
Penitipan Anak, Kelompok Bermain, maupun Taman Kanak-Kanak, berarti berada dalam pengasuhan keluarga. Untuk itu maka orang tua juga merupakan sasaran tidak langsung dari program PAUD guna memperoleh model pengasuhan yang tepat (Diknas, 2006:07).

Selanjutnya Yussen \& Santrock (1980:373) mengatakan bahwa sosialisasi anak sangat terkait dengan orang-orang di sekeliling anak yang disebut agen sosial, yaitu setiap orang yang berhubungan dengan seorang anak misalnya ayah dan ibunya, pengasuh, teman sebaya, guru dan keluarga lainnya dan orang tersebut mempengaruhi cara anak berperilaku. Dalam kaitan itu pula Feeney (2006:55) mengemukakan bahwa sebagian besar nilai-nilai dan pelaksanaan program pendidikan anak tumbuh dari nilai anak dalam suatu masyarakat yang diadopsi secara turun temurun, di antaranya juga dipengaruhi oleh pemimpin agama, pembaharu masyarakat, dan pendidik di masa sebelumnya Selanjutnya kebiasaan dan kebudayaan yang berlaku secara turun temurun tersebut mengalami pergeseran nilai bersamaan dengan menurunnya kemampuan pemerintah, masalah ekonomi masyarakat, pengetahuan orang tua dan masyarakat, serta pengaruh agen sosial serta nilai anak dalam suatu masyarakat.

\section{Motivasi}

Setiap orang berperilaku mesti didorong oleh sesuatu yang menggerakkan untuk berperilaku, yang disebut motif. Dengan demikian kaum kaum ibu yang melibatkan diri dalam mengurus dan mendidik PAUD tentu dilatar belakangi oleh motif tertentu. Dalam kaitan itu Motif tersebut Frymer (1975: 58) mengemukakan bahwa motif berhubungan dengan "mengapa" manusia berperilaku; apa, bagaimana, kapan atau dimana manusia melakukannya. Pertanyaan tentang mengapa manusia melakukan sesuatu tersebut adalah pertanyaan tentang motivasi. Karena itu menurut Hersey dan Blanchard (1988:19) motif terkadang diartikan sebagai kebutuhan, keinginan, dorongan, atau desakan hati pada diri seseorang. Motif mengarah kepada tujuan, baik yang dilakukan secara sadar maupun yang dilakukan secara tidak sadar. Berkenaan dengan istilah motivasi yang dikemukakan di atas Frymer (1975:258) mengemukakan bahwa: (1) motivasi adalah konstruksi kesimpulan, (2) motivasi adalah arahan sebagai implikasi pilihan berbagai variasi dalam pencapaian maksud atau tujuan, (3) motivasi merupakan intensitas sebagai implikasi dari berbagai pilihan yang mungkin dalam tingkatan usaha atau energi yang dibutuhkan dalam pencapaian suatu tujuan.

Berdasarkan uraian tentang motif, kebutuhan, dorongan atau motivasi yang dikemukakan di atas maka istilah yang dipakai adalah motivasi dengan pengertian yang relatif sama.

Selanjutnya McClelland seperti yang dikutip oleh Schermerhorn (1991:137-138) bahwa untuk mengetahui perilaku manusia perlu memahami kebutuhan sosial yang mendorong terjadinya motivasi yaitu: (1) kubutuhan berprestasi (need for achievement), (2) kebutuhan afiliasi (need for affiliation), dan (3) kebutuhan berkuasa (need for power).

\section{Kegiatan Mengabdi / Sukarelawan}

Kegiatan di lembaga PAUD lebih cenderung kepada kegiatan mengafiliasikan diri pada sebuah perkumpulan. Mengingat perkumpulan di lembaga PAUD ini adalah perkumpulan yang dibentuk oleh kelompok ibu - ibu PKK, maka kebanyakan kegiatan ini tidak mempertimbangkan unsur komersil. Kebanyakan siswa tidak dipungut biaya. Kegiatan yang dilaksanakan oleh ibu-ibu ini termasuk kegiatan mengabdi karena pada umumnya para pendidik tidak memperoleh gaji secara profesional. Hal ini juga menjadi pertanyaan mengenai motif keterlibatan mereka dalam lembaga PAUD. Clary \& Snyder, (1999, dalam Baron, Branscombe, dan Byrne, 2008 : 330) melihat bahwa ada sejumlah motif yang membuat seseorang mau terlibat dalam kegiatan "pengabdian". Selengkapnya dapat dilihat pada tabel di bawah ini :

\begin{tabular}{|l|l|}
\hline \multicolumn{1}{|c|}{$\begin{array}{c}\text { Function } \\
\text { served }\end{array}$} & \multicolumn{1}{c|}{ Definition } \\
\hline $\begin{array}{l}\text { Nilai-nilai } \\
\text { (values) }\end{array}$ & $\begin{array}{l}\text { Untuk berekspresi atau bertindak } \\
\text { sesuai dengan nilai kemanusiaan }\end{array}$ \\
\hline $\begin{array}{l}\text { Memahami } \\
\text { (Understanding) })\end{array}$ & $\begin{array}{l}\text { Untuk belajar lebih banyak tentang } \\
\text { dunia atau mengujicobakan } \\
\text { keterampilan yang jarang } \\
\text { digunakan }\end{array}$ \\
\hline $\begin{array}{l}\text { Peningkatan } \\
\text { (Enhancement) }\end{array}$ & $\begin{array}{l}\text { Untuk tumbuh kembang secara } \\
\text { psikologis melalui kegiatan sebagai } \\
\text { volunteer (relawan) }\end{array}$ \\
\hline Karir (Career) & $\begin{array}{l}\text { Untuk memperoleh pengalaman- } \\
\text { pengalaman yang berkaitan untuk } \\
\text { karir }\end{array}$ \\
\hline Sosial (Social) & Untuk memperkuat hubungan sosial \\
\hline $\begin{array}{l}\text { Proteksi } \\
\text { (Protective) }\end{array}$ & $\begin{array}{l}\text { Untuk mengurangi perasaan negatif, } \\
\text { misalnya perasaan bersalah, atau } \\
\text { untuk mengatasi masalah pribadi }\end{array}$ \\
\hline
\end{tabular}

Source ; Based on information in Clary \& Snyder, 1999, dalam Baron, Branscombe, dan Byrne, 2008 : 330 


\section{Developmental Task}

Perkembangan kognitif orang dewasa dapat dilihat pada tujuh tahap penggunaan intelektual dalam konteks sosial, dikemukakan oleh K. Warner Schaie (Schaie \& Willis, 2000, dalam Papalia, Old, \& Feldman, 2009), sebagai berikut:

1. Tahap Pemerolehan - acquisitive stage (masa anak dan remaja). Anak dan remaja memperoleh informasi dan ketrampilan terutama hanya sekadar mendapatkannya, atau sebagai persiapan untuk turut serta di masyarakat.

2. Tahap Pencapaian-achieving stage (akhir masa remaja hingga dewasa awal, atau awal dua puluhan hingga awal tiga puluhan. Dewasa awal tidak lagi memperoleh pengetahuan dan ketrampilan hanya untuk memperoleh pengetahuan dan ketrampilan hanya untuk memperoleh pengetahuan; mereka menggunakan pengetahuan yang mereka ketahui untuk mengejar tujuan, seperti karir dan keluarga.

3. Tahap Tanggung-jawab-responsible stage (akhir tigapuluhan hingga awal enampuluhan).Orang-orang pada usia paruh baya menggunakan pikiran mereka untuk memecahkan masalah praktis yang berhubungan dengan tanggung-jawab terhadap orang lain, seperti anggota keluarga dan karyawan.

4. Tahap Tahap Eksekutif-excecutive stage (tiga puluhan hingga setengah baya).Individuindividu pada tahap ini tampaknya tumpang tindih dengan tahap pencapaian dan tanggungjawab, bertanggung-jawab terhadap sistem masyarakat (seperti pemerintahan atau organisasi bisnis) atau gerakan sosial. Mereka berhadapan dengan hubungan yang kompleks pada banyak tingkatan.

5. Tahap Reorganisasional-reorganizational stage (akhir paruh baya, masa awal dewasa akhir).Di tahap ini individu-individu memasuki usia pensiun dan mengatur ulang kehidupan dan energi dan intelektual mereka di sekitar pengejaran-pengejaran yang bermakna, yang merupakan pekerjaanpekerjaan yang diberi upah.

6. Tahap Reintegrasi-reintegrative stage (dewasa akhir).Keterlibatan sosial pada aktivitas tertentu mulai dilepaskan dan fungsi kognitif mulai terbatas terbatasi oleh perubahan biologis. Dalam tahapan ini seseorang seringkali lebih selektif dalam memilih tugas yang mereka upayakan.
Mereka lebih berfokus pada tujuan kegiatan mereka dan berkonsentrasi pada tugas-tugas yang paling bermakna bagi mereka.

7. Tahap Penciptaan Wrisan-legacy-creating stage (lanjut usia). Orang-orang lanjut usia dapat membuat instruksi atau catatan untuk menentukan kepemilikan dari barang-barang berharga mereka, merencanakan pengaturan pemakaman, dan menyampaikan sejarah secara lisan, atau menuliskan cerita hidup sebagai warisan bagi orang-orang yang mereka cintai.

Keterlibatan kaum ibu di Lembaga PAUD yang berawal dari kelompok PKK atau posyandu sehingga tidak mempertimbangkan unsur komersil, namun kaum ibu tetap antusias menjadi pendidik dan atau pengelola lembaga PAUD. Hal tersebut berkaitan erat dengan perkembangan kognitif individu yang memasuki masa dewasa awal dan menengah di atas, yaitu mulai muncul dan berkembangnya perasaaan untukbertanggung-jawab terhadap keluarga dan lingkungan sosialnya.

Sejalan dengan Durkin (1995 :618-634) yang menyebutkan bahwa wanita dewasa awal (usia sekitar 22 tahun sampai 35 tahun) mulai meningkatkan keterlibatannya dalam aktivitas kemasyarakatan. Sementara wanita dewasa madya (usia sekitar 35 sampai 45 tahun) akan mengalami konflik peran antara tanggung jawab terhadap keluarga dengan aktifitas kemasyarakatan. Jadi selain merasa bertanggung jawab terhadap keluarga sendiri terutama anak, mereka juga melaksanakan aktifitas kemasyarakatan. Dalam penelitian ini kegiatan kemasyarakat yang dimaksud adalah terlibat dalam Lembaga PAUD meskipun tidak ada kepastian adanya penguatan (reward) secara profesional.

\section{METODE PENELITIAN}

Penelitian ini bersifat deskriptif analitik, yaitu data dideskripsikan dengan menggunakan statistik deskriptif, dan dimaknai secara mendalam berdasarkan perspektif emik yaitu penyajian data secara alamiah tanpa melakukan suatu manipulasi atau perlakuan terhadap subjek yang diteliti (Bogdan dan Taylor, 1975:31). Disamping itu data deskriptif yang diisi oleh pengurus dan pendidik PAUD diperkuat melalui triangulasi data melalui observasi dan wawancara pada pengurus dan pendidik PAUD, orang tua, dan masyarakat sekitar sekolah. 


\section{Tempat dan Waktu Penelitian}

Penelitian dilaksanakan di lembaga-lembaga PAUD Kecamatan Grogol Petamburan Jakarta Barat. Sedangkan waktu penelitian berlangsung selama 6 (enam) bulan, yaitu dari bulan April 2010 September 2010.

\section{Ruang Lingkup dan Objek penelitian}

Ruang lingkup dan objek penelitian meliputi hal-hal sebagai berikut :

a. Wilayah penelitian dibatasi pada lembagalembaga PAUD di Wilayah Kecamatan Grogol Petamburan Jakarta Barat DKI Jakarta

b. Sasaran Penelitian adalah kaum perempuan pengelola dan pendidik PAUD yang berada di lembaga-lembaga PAUD di Wilayah Kecamatan Grogol Petamburan Jakarta Barat DKI Jakarta.

c. Penelitian hanya mengkaji motif yang mendorong pengelola dan pendidik PAUD dalam PAUD serta strategi yang dikembangkan untuk keberlanjutan PAUD selanjutnya.

\section{Alat Pengumpul Data}

Alat pengumpulan data yang digunakan dalam penelitian ini adalah angket yang dimaksudkan untuk mengetahui motif pengelola dan pendidik PAUD, observasi, wawancara yang digunakan untuk triangulasi data angket (angket terlampir).

\section{Pengolahan dan Analisis Data}

Berdasarkan data primer dan data sekunder yang diperoleh, maka pengolahan data selanjutnya diolah dan analisis dengan menggunakan analisis :

1. Analisis Statistik Deskriptif : data angket yang diisi oleh responden dianalisis dengan statistik deskriptif guna melihat kecenderungan data tentang motif pengelola dan pendidik PAUD.

2. Analisis Kualitatif: data hasil analisis statistik deskriptif selanjutnya dijelaskan secara kualitatif melalui hasil deskripsi observasi dan wawancara dengan responden, orang tua dan masyarakat sekitar sekolah yang terpilih secara acak.

\section{HASIL PENELITIAN}

Berdasarkan hasil analisis angket yang diberikan kepada pendidik/pengelola PAUD diperoleh data responden sebanyak 91 orang, sedangkan responden yang menjawab pertanyaan dengan lengkap sebanyak 80 orang. Sehubungan dengan itu deskripsi data tentang responden berjumlah 91 orang sedangkan analisis data tentang pendapat responden berjumlah 80 orang.

\section{Deskripsi Data}

\section{Usia}

Usia 40 tahun ke atas dan usia 40 tahun ke bawah jumlahnya berimbang. Data ini menunjukkan bahwa regenerasi bagi pendidik PAUD perlu segera dilakukan.

\section{Status}

Status responden adalah guru dan kepala sekolah. Guru berjumlah 70 orang sedangkan kepala sekolah yang pada umumnya juga bertindak sebagai guru berjumlah 21 orang.

\section{Masa Kerja}

Sebagian besar masa kerja guru antara 3-4 tahun dan yang paling lama antara 4-6 tahun.

\section{Pekerjaan}

Pekerjaan responden antara lain: perusahaan swasta, mengajar bahasa Indonesia bagi orang asing, tutor keaksaraan, guru TK, pegawai asuransi, berdagang, klinik gigi, guru SLTP, disain interior, perusahaan dagang, guru TK, pegawai Mall, kader PKK, perawat rumah sakit, konsultan supervise teknik, CV, restoran, perusahaan elektronik. Keragaman pendidikan ini disamping mengandung kelemahan dari sisi latar belakang pendidik tetapi menjadi suatu kekuatan dalam menghimpun sumber daya dan sumber dana dari masyarakat.

Transportasi:

Sebagian besar responden pergi bekerja dapat dilakukan dengan berjalan kaki. Kenyataan ini sangat menguntungkan karena mobilitas pendidik lebih cepat dan tidak membutuhkan biaya.

\section{Pendidikan}

Rata-rata pendidikan pendidik adalah SLTA. Sedangkan tenaga pengajar yang diharapkan minimal diploma pendidikan anak. data ini menggambarkan bahwa tugas pemerintah dalam upaya meningkatkan pendidikan dan pelatihan bagi pendidik PAUD makin besar. 


\section{Faktor-Faktor yang Melatarbelakangi Motivasi Kaum Ibu sebagai Pengurus dan Pendidik Lembaga PAUD.}

Dalam pembahasan bagian ini akan ditekankan pada peringkat jawaban atau respon: pertama peringkat 1 dan 2 yang menjadi prioritas bagi pendidik dan pengelola PAUD, dan kedua peringkat 7 dan 8 yang di anggap tidak menjadi prioritas bagi pendidik dan pengelola PAUD dalam keterlibatannya sebagai pendidik atau pengurus PAUD.

Responden memberikan jawaban pada peringkat satu bahwa pengabdian yang diberikan mereka pada PAUD disebabkan oleh adanya ke inginan untuk membantu orang lain. Disamping dapat membantu orang lain mereka merasakan bahwa pengabdian di lembaga PAUD ini juga memberikan pengalaman dari anak didik.

Senada dengan pernyataan pada bagian A bahwa dapat membantu orang lain menumbuhkan harga diri responden artinya semakin banyak mereka membantu orang maka harga diri akan naik pula. Sementara itu pengalaman yang diperoleh dalam pengabdian di PAUD juga diikuti oleh kemampuan responden berupa pengetahuan dan keterampilan yang mereka miliki. Hal ini diungkapkan bahwa mereka dapat menerapkan ilmu yang mereka peroleh selama ini.

Selanjutnya jawaban pada peringkat dua terakhir atau peringkat 7 dan 8 menunjukkan bahwa dengan mengikuti kegiatan di lembaga PAUD kurang menunjukkan hasil dalam mengurus anak. Hal ini dapat dipahami bahwa sebagain besar pendidik dan pengurus berusia lanjut sehingga mereka di rumah tidak mengurus anak lagi. Disamping itu responden juga tidak melibatkan diri di PAUD untuk melepaskan diri dari permasalahan di rumah tangga. Sebaliknya kegiatan di lembaga PAUD memberikan kesempatan kepada mereka untuk berbagi dalam bentuk membantu orang lain sekaligus dapat memeperoleh pengalaman baru dalam kehidupan.

\section{KESIMPULAN DAN SARAN}

Berdasarkan hasil penelitian maka dapat disimpulkan bahwa:

1. Keterlibatan ibu-ibu dalam PAUD didorong oleh keinginan yang kuat membantu orang lain, merasa dihargai dan pekerjaan tersebut diangap sebagai ibadah.

2. Disamping keinginan untuk membantu orang lainketerlibatan ibu-oibu ini juga diorong oleh motivasi berprestasi: manambah pengalaman, menerapkan ilmu, pengembangan ide dari penagalam kerja responden sebelumnya. Sebagain kecil diantara mereka ini dijadikan sebagai batu loncatan untuk karir berikutnya.

3. Keterlibatan ibu-ibu didorong oleh motif afiliasi yaitu untuk diterima sebagai anggota profesi PAUD bukan afiliasi dengan kerukunan Warga karena umunya ibu-ibu ini aktif dalam kegiatan masyarakat. Atas dasar itu pula bahwa motif kekuasaan bukan merupakan tujuan ibu-ibu dalam melibatkan diri di PAUD

4. Untuk mengantisipasi permasalahan pengembangan PAUD diperlukan sosialisasi PAUD, mencari alernatif pemasukan dana selain bersumber dari orang tua murid, meningkatkan kreativitas pendidik melalui pelatihan

Berdasarkan hasil penelitian dan kesimpulan yang dikemukakan sebelumnya maka dapat disarankan hal sebagai berikut:

1. Motivasi ibu-ibu yang terlibat dalam PAUD perlu diperkuat dengan dukungan pemerintah dalam bentuk wadah komu-nikasi antar pendidik dan pemerintah, RT, RW setempat guna mendukung penyelenggaraan PAUD.

2. Ibu-ibu pendidik PAUD khususnya yang belum memiliki dasar pendidikan anak perlu diberikan pelatihan guna meng-optimalkan potensi yang dimilikinya.

3. HIMPAUDI secara berkala berupaya untuk membangun komunikasi antar sejawat untuk bertukar informasi dalam upaya menyelesaikan masalah-masalah yang dihadapi pendidik PAUD.

4. Pendidik PAUD, khususnya yang berusia muda diupayakan beasiswa dari Pendidik dan Tenaga Kepoendidikan Nonformal (PTKPNF) untuk pendidikan lanjut.

\section{DAFTAR PUSTAKA}

[1] Albrecth, Karl Pengembangan Organisasi: Pendekatan Sistem yang Menyeluruh untk Mencapai Perubahan Positif dalam Setiap Organisasi Usaha Diterjemahkan oleh Drs Syariful Anwar Bandung: Angkasa, 1993.

[2] Ass'ad, Moh Kepemimpinan Efektif dalam Perusahaan: Suatu Pendekatan Psikologi Yogyakarta: Liberty, 1982.

[3] Baron, Robert A.; Branscombe, Nyla; \& Byrne, Donn; 2008. Social Psychology Twelfth Edition; Boston : Pearson Allyn \& Bacon. 
[4] Byrne, Donn. Response to Attitude SimilarityDissimilarity as a Function of Afiliation Needs Journal of Personality, 1962.

[5] Frymer, Jack R. "Motivation: The Mainspring and Gyroscope of Learning" Teaching Today Task and Challenges, Editor J. Michael Palardy. New York: Macmillan Publishing Co. Inc., 1975.

[6] Gibson James L., etall Organisasi Perilaku: Perilaku, Struktur dan Proses Editor Agus Dharma Jakarta: Pnerbit Erlanga, 1996.

[7] Hamilton, Richard dan Elizabeth Ghatala, Learning and Instruction_New York: McGraw Hill, Inc., 1994.

[8] Hersey, Paul and Kenneth H. Blanchard. Management of Organizational Behavior: Utilizing Human resources, Fifth Edition. Englewood Cliff New Jersey: Prentice Hall, 1988.

[9] Lindgren, Hendry Clay. An Introduction to Social Psychology. Second Edition, New York: Wiley Eastern Limited, 1973.
[10] Porter, Michael. "Creating Tomorrow's Advantages", Re thinking the Future, Editor Rowan Gibson, London: Nicholas Brealey Publishing, 1997.

[11]Robin Stephen P., Teori Organisasi: Struktur, Desain dan Aplikasi Edisi 3 Alih Bahasa oleh Jusuf Udaya, lic., Ec. Jakarta: Penerbuit Arcan, 1994.

[12] John R. Schemerhorn, Jr., Managing Organizational Behavior, Fourth Edition New York: John Wiley \& Sons, Inc., 1991.

[13] Stoner, James A.F., dan R. Edward Freeman Manajmen Edisi ke-5 Diterjemahkan oleh Wilhelminus W. Bakowatun Jakarta: Intermedia, 1994.

[14] Warr, Peter Psikologi Perubahan dan perundingan Kolektif Diterjemahkan oleh Aloysius L. Madja Seri Manajemen No. 99 Jakarta: PT Pustaka Binaman Presindo, 1984. 